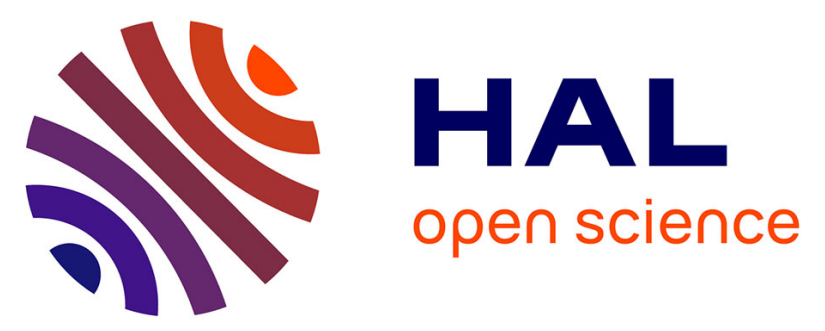

\title{
Pregnancy outcome after first trimester exposure to ionizing radiations
}

Lucie Guilbaud, Delphine Beghin, Ferdinand Dhombres, Eléonore Blondiaux, Stéphanie Friszer, Hubert Ducou Le Pointe, Elisabeth Elefant, Jean-Marie Jouannic

\section{To cite this version:}

Lucie Guilbaud, Delphine Beghin, Ferdinand Dhombres, Eléonore Blondiaux, Stéphanie Friszer, et al.. Pregnancy outcome after first trimester exposure to ionizing radiations. European Journal of Obstetrics \& Gynecology and Reproductive Biology, 2019, 232, pp.18-21. 10.1016/j.ejogrb.2018.11.001 . hal-02314031

\section{HAL Id: hal-02314031 \\ https://hal.sorbonne-universite.fr/hal-02314031}

Submitted on 11 Oct 2019

HAL is a multi-disciplinary open access archive for the deposit and dissemination of scientific research documents, whether they are published or not. The documents may come from teaching and research institutions in France or abroad, or from public or private research centers.
L'archive ouverte pluridisciplinaire $\mathbf{H A L}$, est destinée au dépôt et à la diffusion de documents scientifiques de niveau recherche, publiés ou non, émanant des établissements d'enseignement et de recherche français ou étrangers, des laboratoires publics ou privés. 


\section{Pregnancy outcome after first trimester exposure to ionizing radiations}

\section{Lucie Guilbauda ${ }^{\mathrm{a}, *}$}

lucie.guilbaud@gmail.com

Delphine Beghin

Ferdinand Dhombres ${ }^{\mathrm{a}}$

Eléonore Blondiaux ${ }^{c}$

Stéphanie Friszer ${ }^{a}$

Hubert Ducou Le Pointe ${ }^{c}$

Elisabeth Éléfant

Jean-Marie Jouannic ${ }^{a}$

aDepartment of Fetal Medicine, Armand Trousseau Hospital, APHP, Sorbonne University, UPMC Paris 6 University, Paris, France

${ }^{\mathrm{b}}$ Centre de Référence sur les Agents Tératogènes, Armand Trousseau Hospital, APHP, Paris, France

'Department of Radiology, Armand Trousseau Hospital, APHP, Sorbonne University, UPMC Paris 6 University, Paris, France

${ }^{*}$ Corresponding author at: Service de Médecine Fœtale, Hôpital Armand Trousseau, 26 avenue du Docteur Arnold Netter, 75012 Paris, France.

\section{Abstract}

Objective

To evaluate the effects of ionizing radiation exposure during the first trimester of pregnancy in usual clinical situations.

\section{Study design}

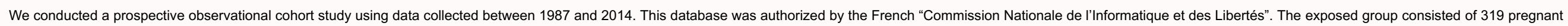

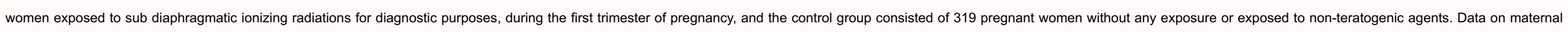
history and radiations exposure were collected on first contact, and pregnancy outcomes were documented at follow-up. An univariate analysis was performed to compare both groups for the main outcomes.

Results

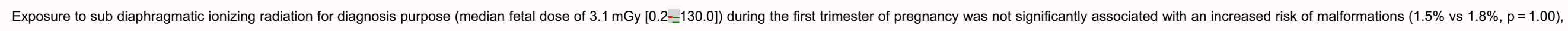
miscarriage $(7.8 \%$ vs $7.2 \%, p=0.88)$, in utero fetal death $(0.3 \%$ vs $0 \%, p=1.00)$ or fetal growth restriction $(5.4 \%$ vs $3.5 \%, p=0.62)$.

Conclusion

Pregnant women exposed to irradiant diagnostic procedures do not present a higher risk of malformations, miscarriage, in utero fetal death or fetal growth restriction and should be reassured, even if the examination focused on the pelvis.

Keywords: Pregnancy; Diagnostic radiations; Fetal exposure; Teratogenesis; lonizing radiations

\section{Introduction}




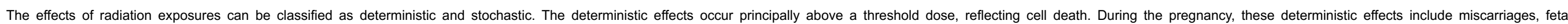

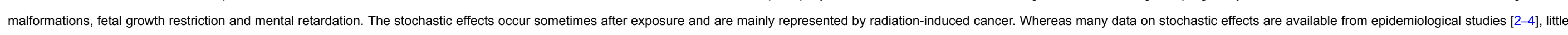

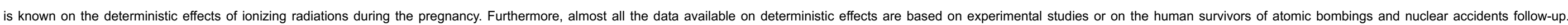
According to these studies, prenatal exposure to radiations may lead to different complications, depending on the gestational age at exposure [5-15].

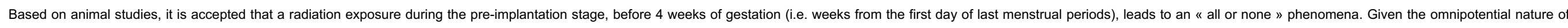

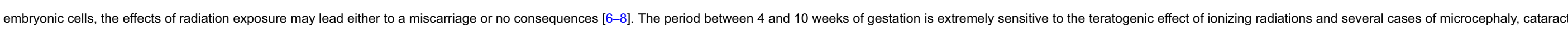

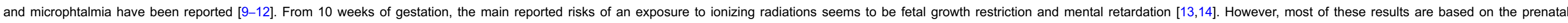
exposure to much higher doses than those delivered in case of diagnostic irradiant examinations.

The objective of our study was to compare pregnancy outcomes in women with and without first trimester exposure to diagnostic sub diaphragmatic ionizing radiations.

\section{Materials and Mmethods}

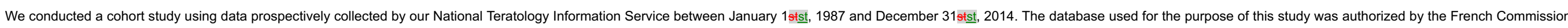
Nationale de l'Informatique et des Libertés (CNIL).

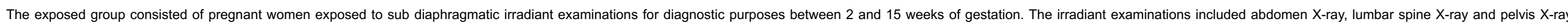
examinations, hysterosalpingography, intravenous urogram, abdomen and pelvis computerized tomography scan (CT scan), lumbar spine CT scan, cholangiography and abdominal scopic examinations.

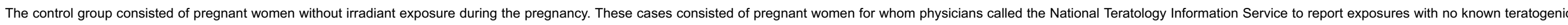

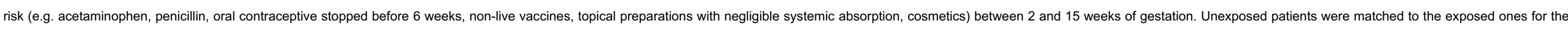
calendar month of the first call to the center.

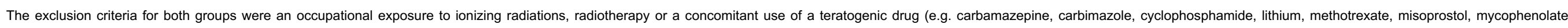
phenobarbital, retinoids, thalidomide, valproic acid and vitamin $\mathrm{K}$ antagonists)

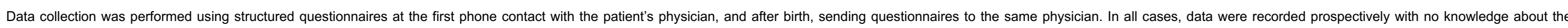

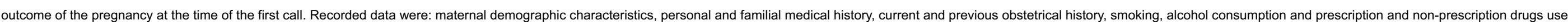

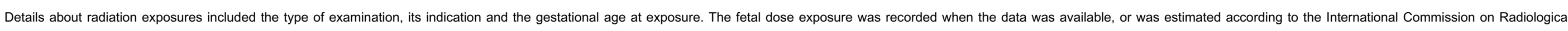

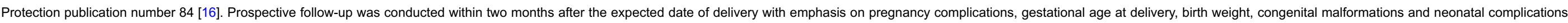
An induced abortion before 14 weeks for personal reasons was defined as a voluntary termination of pregnancy, and a termination of pregnancy for a medical reason was defined as an elective termination of pregnancy.

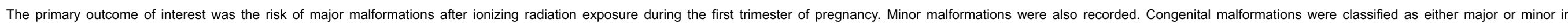

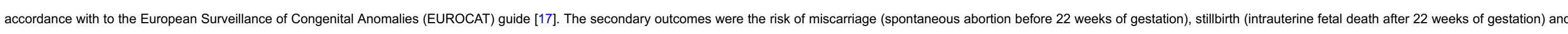
fetal growth restriction defined as a birthweight lower than the 5 thth percentile, due to this exposure.

\section{Statistics}

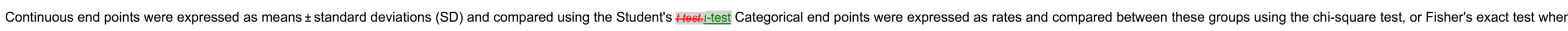
the assumptions for the chi-square test were not met. A P-value less than 0.05 was considered significant. Statistical analyses were performed using R 3.3.2 Statistical Software.

\section{Results}

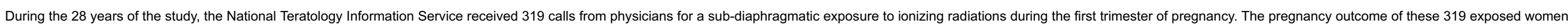




\section{Table 1 Patient characteristics.}

\section{alt-text: Table 1}

\section{Characteristic}

\section{Maternal age (years)}

Primiparous

Significant disease before pregnancy

History of congenital malformation

Teratogenic drugs exposure ${ }^{b}$

Smoke during pregnancy

\section{Alcohol during pregnancy}

Multiple pregnancies a defined as a risk factor for miscarriage, fetal growth retardation, in utero fetal death, chromosomal aberrations or congenital malformation

$30.4 \pm 0.7$
$83(57.5 \%)$
$(0.3 \%)$
$(0.6 \%)$
$(2.8 \%)$
$(1.3 \%)$
$(0.6 \%)$

$$
\begin{gathered}
\text { Radiations } \\
\mathrm{N}=319 \\
\text { mean } \pm \mathrm{SD}
\end{gathered}
$$$$
\text { mean } \pm \text { S }
$$$$
\mathrm{n}(\%)
$$

$$
\begin{gathered}
\text { Control group } \\
\mathrm{N}=319 \\
\text { mean } \pm \text { SD } \\
\mathrm{n}(\%)
\end{gathered}
$$

\begin{tabular}{|l|l|}
\hline $30.8 \pm 1.4$ & 0.47 \\
\hline $206(64.6 \%)$ & 0.08 \\
\hline $3(0.9 \%)$ & 0.62 \\
\hline $2(0.6 \%)$ & 1.00 \\
\hline 0 & 1.00 \\
\hline $12(3.8 \%)$ & 0.66 \\
\hline 0 & 0.12 \\
\hline $1(0.3 \%)$ & 1.00 \\
\hline
\end{tabular}

b e.g. acitretin, antivitamin $\mathrm{K}$, isotretinoin, methotrexate, mycophenolate, or sodium valproate.

\begin{tabular}{|c|c|c|c|}
\hline Examination & $\begin{array}{c}\text { Number of patients } \\
\mathrm{n}(\%)\end{array}$ & $\begin{array}{l}\text { Common } \\
\text { indication }\end{array}$ & $\begin{array}{c}\text { Term of exposure (weeks) } \\
\text { mean } \pm S D\end{array}$ \\
\hline Abdomen X-ray & $105(32.9 \%)$ & Abdominal pain & $5.0 \pm 2.6$ \\
\hline Abdomen/pelvis CT scan & $72(22.6 \%)$ & Abdominal pain & $4.9 \pm 2.6$ \\
\hline Lumbar spine X-ray & $66(20.7 \%)$ & Lumbar spine pain & $4.0 \pm 1.0$ \\
\hline Pelvis X-ray & $54(16.9 \%)$ & Pelvis pain & $3.4 \pm 2.1$ \\
\hline Hysterosalpingography & $38(11.9 \%)$ & Infertility investigation & $4.9 \pm 1.7$ \\
\hline Intravenous urogram & $32(10.0 \%)$ & Suspicion of urolithiasis & $4.4 \pm 2.3$ \\
\hline Lumbar spine CT scan & $27(8.5 \%)$ & Lumbar spine pain & $3.8 \pm 1.5$ \\
\hline Fluoroscopy & $21(6.6 \%)$ & Installation of a double $\mathrm{J}$ catheter & $4.4 \pm 1.7$ \\
\hline Cholangiography & $12(3.8 \%)$ & Intra-operative cholangiography during cholecystectomy & $5.3 \pm 1.8$ \\
\hline
\end{tabular}

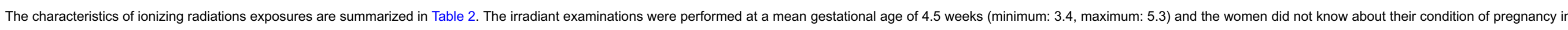

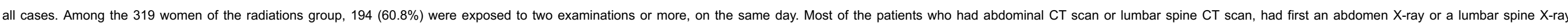

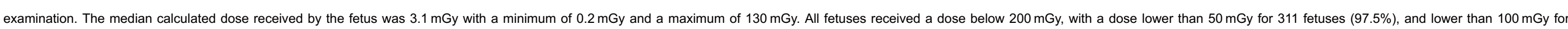

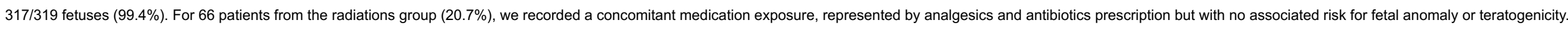

Table 2 Radiations exposures: 


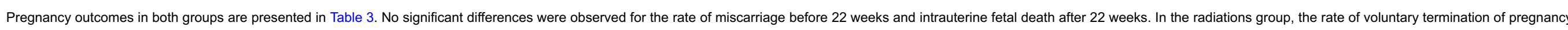

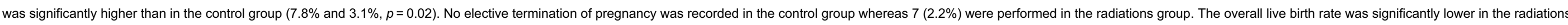

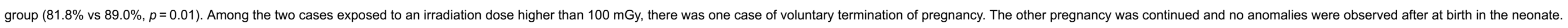

Table 3 Pregnancy and neonatal outcomes.

alt-text: Table 3

Chromosomal aberration

\section{Outcome}

\section{Gestational age at birth ${ }^{a}$ (weeks)}

Birth weight $^{\mathrm{a}}(\mathrm{g})$

Birth weight $<5^{\text {th }}$ percentile ${ }^{\text {a }}$

Major malformations ${ }^{a}$

Minor malformations ${ }^{a}$

VTP: Voluntary term
a among live births.

\begin{tabular}{|c|c|c|c|}
\hline Outcome & $\begin{array}{c}\text { Radiations } \\
\mathrm{N}=319 \\
\text { mean } \pm \text { SD } \\
\mathrm{n}(\%)\end{array}$ & $\begin{array}{c}\text { Control group } \\
\mathrm{N}=319 \\
\text { mean } \pm \mathrm{SD} \\
\mathrm{n}(\%)\end{array}$ & $p$ \\
\hline Miscarriage before 22 weeks & $25(7.8 \%)$ & $23(7.2 \%)$ & 0.88 \\
\hline VTP & $25(7.8 \%)$ & $10(3.1 \%)$ & 0.02 \\
\hline ETOP & $7(2.2 \%)$ & 0 & 0.02 \\
\hline Ectopic pregnancy & $1(0.3 \%)$ & $1(0.3 \%)$ & 1.00 \\
\hline IUFD after 22 weks & $1(0.3 \%)$ & 0 & 1.00 \\
\hline Live birth & $261(81.8 \%)$ & $284(89.0 \%)$ & 0.01 \\
\hline Gestational age at birth ${ }^{a}$ (weeks) & $39.2 \pm 0.3$ & $39.5 \pm 0.2$ & 0.26 \\
\hline Birth weight $^{\mathrm{a}}(\mathrm{g})$ & $3288.7 \pm 68.5$ & $3328.7 \pm 51.5$ & 0.66 \\
\hline Birth weight $<5^{\text {th }}$ percentile ${ }^{a}$ & $14(5.4 \%)$ & $11(3.5 \%)$ & 0.62 \\
\hline Major malformations ${ }^{a}$ & 0 & 0 & 1.00 \\
\hline Minor malformations $\mathrm{s}^{\mathrm{a}}$ & $4(1.5 \%)$ & $5(1.8 \%)$ & 1.00 \\
\hline Chromosomal aberration & $6(1.9 \%)$ & 0 & 0.03 \\
\hline
\end{tabular}

\section{,}

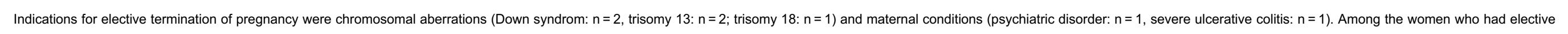

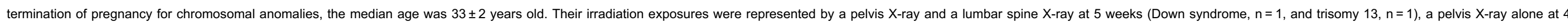

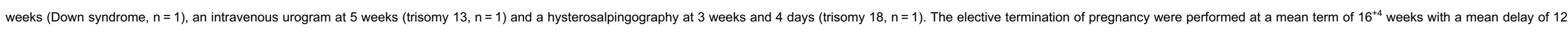
weeks between the exposure and the elective termination of pregnancy.

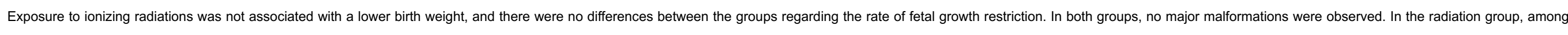

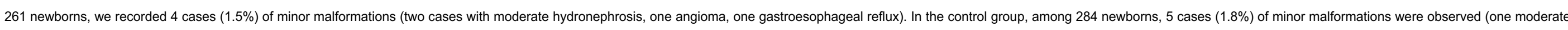

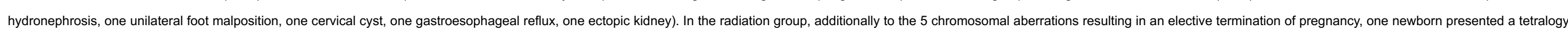
of Fallot associated with a 22q1.1 deletion. The chromosomal anomaly rate was significantly higher in the exposed group with no cases in the control group $(p=0.03)$.

\section{Discussion}

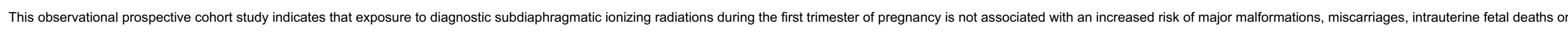
fetal growth restrictions. 


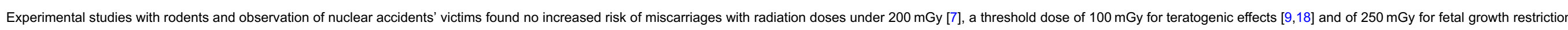

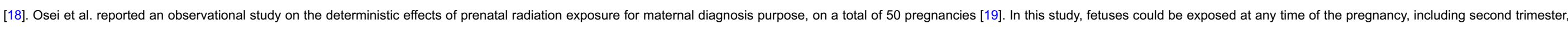

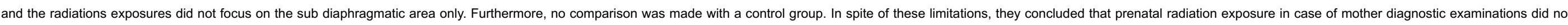

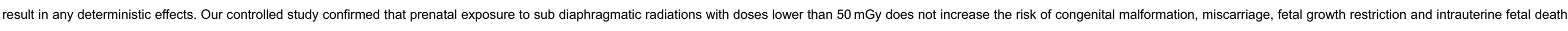
Our results are consistent with the recent systematic review of Gomes et al. and provide additional clinical arguments to support patients reassurance [20].

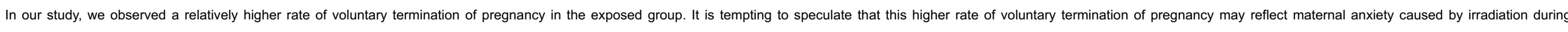

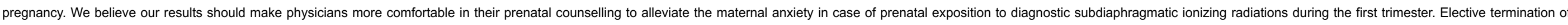
pregnancy's rate was also significantly higher in the radiation group, but directly related to the chromosomal aberrations presented in this group. This high rate of chromosomal aberrations is difficult to explain, except as a selection bias.

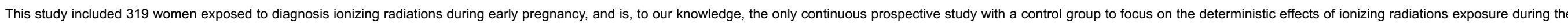

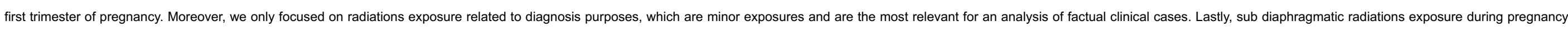

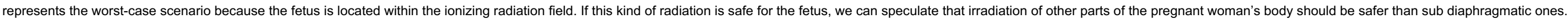

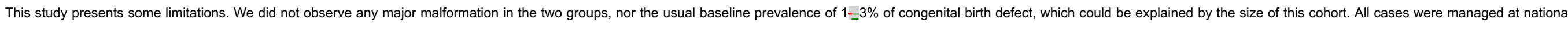

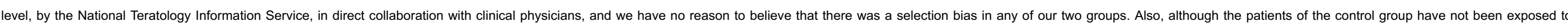

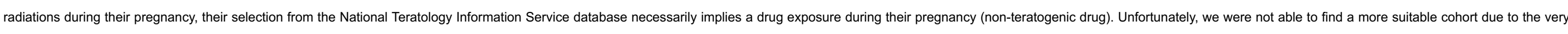

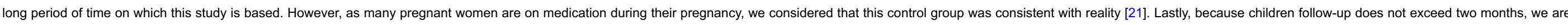
not able to provide data about mental retardation risk or carcinogenic risk. In this setting, the effect of prenatal exposure to low doses could not be studied.

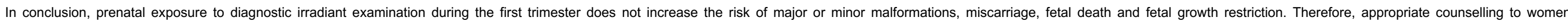

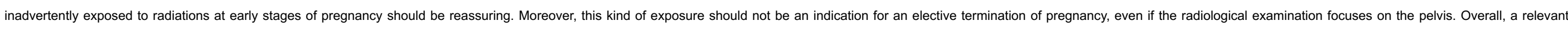

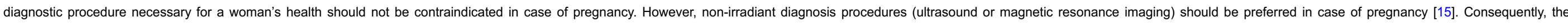
diagnosis of pregnancy should be excluded in all women of childbearing age, before any irradiant procedure.

\section{References}

[1] S. Ratnapalan, N. Bona, K. Chandra and G. Koren, Physicians' perceptions of teratogenic risk associated with radiography and CT during early pregnancy, AJR Am J Roentgenol I182 (5), 2004, 1107-9.

[2] J.F. Bithell and A.M. Stewart, Pre-natal irradiation and childhood malignancy: a review of British data from the Oxford Survey, Br J Cancer $\$ 31$ (3), $1975,271-287$.

[3] Y. Yoshimoto, Cancer risk among children of atomic bomb survivors. A review of RERF epidemiologic studies. Radiation Effeets Research FoundationJAMA.effects research foundation, JAMA 264 (5), 1990, 596-600.

[4] D.L. Preston, ‥ ․ Cullings, A. Suyama, et al., Solid cancer incidence in atomic bomb survivors exposed in utero or as young children, J Natl Cancer Inst

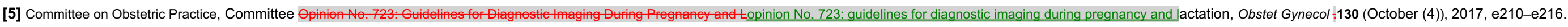

[6] D.M. Schlesinger and R.L. Brent, Effects of X irradiation during preimplantation stages of gestation on cell viability and embryo survival in the mouse, Radiat Res 75 (1), $1978,202-216$.

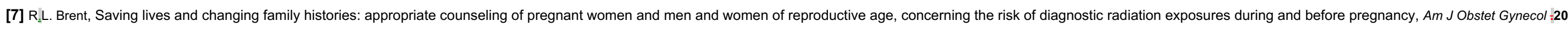
(1), 2009, 4-24.

[8] M.C. Haeusler, A. Berghold, W. Schoell, P. Hofer and M. Schaffer, The influence of the post-Chernobyl fallout on birth defects and abortion rates in Austria, Am J Obstet Gynecol-167 (4 Pt 1), $1992,1025-1031$.

[9] P.U. Devi, R. Baskar and M.P. Hande, Effect of exposure to low-dose gamma radiation during late organogenesis in the mouse fetus, Radiat Res \$138 (1), $1994,133-138$.

[10] P.U. Devi and R. Baskar, Influence of gestational age at exposure on the prenatal effects of gamma-radiation, Int J Radiat Biol 70 (1), $1996,45-52$. 
[11] M. Otake and W.J. Schull, Radiation-related small head sizes among prenatally exposed A-bomb survivors, Int J Radiat Biol 63 (2), 1993, 255-270.

[12] R. Rugh, ‥ Duhamel, A. Chandler and A. Varma, Cataract development after embryonic and fetal x-irradiation, Radiat Res 22, 1964, 519-534.

[13] M. Otake, W.J. Schull and S. Lee, Threshold for radiation-related severe mental retardation in prenatally exposed A-bomb survivors: a re-analysis, Int J Radiat Biol 70 (6), $1996,755-763$.

[14] W.J. Schull and M. Otake, Cognitive function and prenatal exposure to ionizing radiation, Teratology 59 (4), 1999, 222-226.

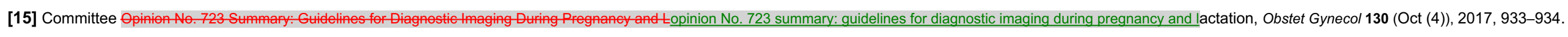

[16] International Gommission on Radiological Pcommission on radiological protection. Pregnancy and medical radiation, Ann ICRP 3030 (1), 2000, iii - viii, 1-43.

[17] EUROCAT Guide, available at http://www.eurocat-network.eu/aboutus/datacollection/guidelinesforregistration/guide1_4.

[18] M. De Santis, E. Di Gianantonio, G. Straface, et al., lonizing radiations in pregnancy and teratogenesis: a review of literature, :Reprod Toxicol Elmsford N 20 (3), $2005,323-329$.

[19] E.K. Osei and K. Faulkner, Fetal doses from radiological examinations, Br J Radiol 72 (860), 1999, 773-780.

[20] M. Gomes, A. Matias and F. Macedo, Risks to the fetus from diagnostic imaging during pregnancy: review and proposal of a clinical protocol, Pediatr Radiol $\underline{45}$ (December (13)), $2015,1916-1929$.

[21] I. Lacroix, C. Damase-Michel, M. Lapeyre-Mestre and J.L. Montastruc, Prescription of drugs during pregnancy in France, Lancet 356 (9243), $2000,1735-1736$.

\section{Queries and Answers}

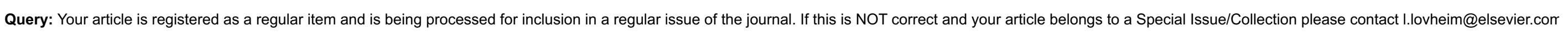
immediately prior to returning your corrections.

Answer: ok

Query: The author names have been tagged as given names and surnames (surnames are highlighted in teal color). Please confirm if they have been identified correctly.

Answer: Yes

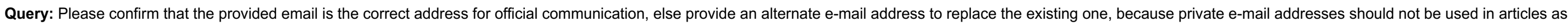
the address for communication.

Answer: ok

Query: Please check the hierarchy of the section headings and correct if necessary.

Answer: ok

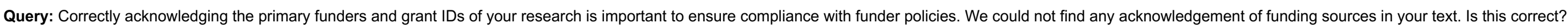
Answer: Yes

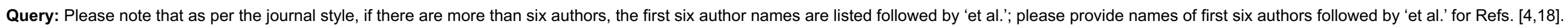
Answer: ok 